\title{
Food subsidies from fisheries to continental shelf benthic scavengers
}

\author{
Michel J. Kaiser*, Jan Geert Hiddink \\ School of Ocean Sciences, College of Natural Sciences, Bangor University, Menai Bridge, Anglesey LL59 5AB, UK
}

\begin{abstract}
Fisheries generate carrion as a result of material discarded at sea from fishing boats, and as a result of the direct mortality of organisms on the seabed that is caused by the bottom trawling gears. It is unclear whether the increases in the population sizes in scavenging seabirds that have been partially attributed to discarding practices might be mirrored in populations of benthic scavengers. We used a previously published and field-validated, size-based model to calculate the effects of bottom fishing on benthic invertebrate production and production of invertebrate carrion at the seabed in the North Sea. This estimate was combined with previously published estimates of discarded fish carrion that reaches the seabed. Fishing decreases benthic biomass; this means that benthic production is also reduced. In this process, fishing increases production in the short term ( 2 to $3 \mathrm{~d}$ ) by generating carrion. However, the production of carrion only compensates for $22 \%$ of the reduction in production. Calculations of ash free dry weight of carrion produced per unit area were similar to other previous estimates for the North Sea, which indicated that fisheries-generated carrion was sufficient to sustain benthic carnivores for only approximately $3 \mathrm{~d} \mathrm{yr}^{-1}$.
\end{abstract}

KEY WORDS: Benthic scavengers · Energy subsidies $\cdot$ Model $\cdot$ Fishing disturbance

\section{INTRODUCTION}

Food falls in the deep sea have important ecological implications for the patchiness of diversity in this environment (Stockton \& DeLaca 1982), and may provide as much as $11 \%$ of the benthic community's respiratory requirements (Smith 1985). Surprisingly, the ecological implications of these energy subsidies are less well studied for shallower continental shelf systems. This dichotomy has arisen, in part, due to the different approaches to sampling the faunal assemblage in these 2 environments: shallow continental shelf assemblages of mobile macrofauna are typically sampled with small towed trawls, whereas the mobile fauna of the deep sea are typically studied using baited underwater cameras (see papers in this theme section). These differences in approach have inevitably skewed our knowledge of deep-sea fauna towards those taxa that are attracted to carrion, whereas far less is known specifically about carrion-feeding taxa on the continental shelf. In addition, food falls and other sources of carrion that occur on the continental shelf, occur against a background of higher levels of primary production and natural and anthropogenic disturbances such that the effects of energy subsidies have been considered to be insignificant (Hall 1994). In addition to this, most circalittoral scavengers may be facultative rather than obligate scavengers (Britton \& Morton 1994) and are unlikely to show the specialised morphological and life-history adaptations that are conducive to subsistence upon sporadic pulses of carrion (but see Kaiser \& Moore 1999).

On a global scale, fisheries are a major source of carrion generated through discarded bycatches of organisms for which there is no market, for which fishers have no quota, or that are illegal to land. It is estimated that 27 million tonnes of such bycatch are discarded annually (Alverson et al. 1994). This figure is likely an underestimate, as it represents only reported bycatch and does not account for the inevitable increase in the proportion of discards as the biomass of legal-sized fishes diminishes further under a regime of continuing over-exploitation, although technological improvements in gear design have helped to reduce this prob- 
lem (Hall \& Mainprize 2005, Broadhurst et al. 2006). In addition to the material retained in fishing nets that is subsequently discarded, demersal trawls kill or damage varying proportions of different benthic taxa in the path of the trawl (Bergman \& Van Santbrink 2000, Kaiser et al. 2006). The mean instantaneous mortality for different benthic taxa varies considerably (from 21 to $98 \%$ ) according to their structural characteristics and position in the habitat (Table 1). Thus, fisheries generate considerable amounts of carrion, from both discards and incidental mortality on the seabed. This carrion acts as an energy subsidy to marine food webs by making available resources that would otherwise be unattainable for organisms at particular trophic levels.

Ecologists recognize the importance of resource subsidies from donor ecosystems and habitats to sustaining food webs in recipient ecosystems or habitats (Polis et al. 1997, Paetzold et al. 2005). In situations where food webs are subsidised, consumer populations can sometimes become enhanced (Polis et al. 1996), although this may depend on the quantity and temporal variability of the subsidy and on the life-history characteristics of the consumer species. Where consumers do increase in abundance as a result of food subsidies, several top-down effects may occur in the community. Subsidised consumers may depress in situ prey species; if these species are key to community structure, the effects could be far-reaching. When large numbers of subsidised predators depress herbivore populations, primary producers can become more

Table 1. Mean instantaneous percentage mortality (up to $1 \mathrm{~d}$ after initial fishing gear impact) of different Phyla grouped by fishing gear type (beam or otter trawls) and habitat (gravel, sand, muddy sand, mud and biogenic). Phylum-Ann: Annelida, Cru: Crustacea, Mol: Mollusca, Ech: Echinodermata, CnP: Cnidaria and Porifera, Oth: Other Phyla. Data adapted from Kaiser et al. (2006)

\begin{tabular}{|llc|}
\hline $\begin{array}{l}\text { Gear type } \\
\text { and habitat }\end{array}$ & Phylum & $\begin{array}{c}\text { Mean Day 1 } \\
\text { change (\%) }\end{array}$ \\
\hline Beam trawls & Ann, Cru, Ech, Moll & -42 \\
Gravel & Ann & -21 \\
Sand & Cru, Ech, Moll & -75 \\
& Ann, Cru, Ech, Moll & -29 \\
Muddy sand & Oth & -54 \\
& & \\
Otter trawls & CnP & -62 \\
Biogenic & Moll & -91 \\
& Ech, Oth & -73 \\
Gravel & CnP, Cru, Ech, Moll & +3 \\
Sand & Ann, CnP, Cru, Ech, Moll & -15 \\
Muddy sand & Ann, Moll & -26 \\
& Cru & -81 \\
Mud & Ann & -24 \\
& Moll & -37 \\
& Cru, Ech, Oth & -28 \\
\hline
\end{tabular}

abundant (Polis et al. 1996). For energy subsidies to have a population level effect, they must be sufficient in magnitude and frequency and must be predictable (Polis et al. 1996). On this basis, carrion generated through fisheries activities might be considered to have the potential to lead to population level changes in marine scavengers. The population level responses of avian scavengers to fisheries carrion is well documented, with changes in the population size of particular species that are predicated upon competitive capabilities and limitations imposed by foraging ability (Furness et al. 2007, this volume). These observations have prompted speculation that fisheries-generated carrion that reaches the seabed could lead to an increase in the population size of fish and benthic scavenger populations that can utilise fisheries carrion as a source of energy (Link \& Almeida 2002). The purpose of the present paper was to examine the evidence for the latter supposition by reviewing briefly what we understand about scavenger behaviour in relation to fisheries carrion. We then examine through a modelling approach whether the inputs of carrion are likely to meet the criteria defined by Polis et al. (1996).

\section{Responses of scavengers to fisheries carrion}

Direct observational studies of the response of marine aquatic scavengers to fisheries discards are limited and have been undertaken primarily in northern Europe and Australia, with a few studies undertaken in North America and the Mediterranean. These studies are divided into 3 main categories: (1) laboratory observations of different scavenging taxa consuming discarded material from fisheries, (2) analysis of the diets of scavengers in areas subjected to fishing disturbance compared with appropriate control conditions, and (3) direct quantification of scavengers using baited traps or video cameras.

Although the species that consume fisheries discards differ between studies undertaken in the northern and southern hemisphere, the groups of scavengers were broadly similar, e.g. seabirds (Furness et al. 2007), fishes, crustaceans and gastropods. The composition of scavenger assemblages may vary considerably with habitat type (Ramsay et al. 1997). The outcome of interactions over carrion may be related to competitive ability that is also influenced by the background density of a particular species (Ramsay et al. 1997). Accordingly, the responses of different scavenger species to increasing inputs of carrion may vary between habitats, and we might expect to see different population-level responses at a habitat scale that is smaller than the scale applying to scavenging seabirds (Furness et al. 2007). 


\section{Laboratory observations}

Berghahn (1990) studied benthic scavenger feeding on discarded fish from shrimp trawl fisheries in the shallow waters of the Wadden Sea, and found that the shrimps Crangon crangon, the crabs Liocarcinus holsatus Fabricus and Carcinus maenas, the starfish Asterias rubens and the whelks Buccinum undatum L. feed on freshly killed discards presented in the laboratory. Berghahn (1990) also calculated the food intake rates for C. maenas and C. crangon, and found that these were 0.40 to 1.33 and 0.034 to $0.093 \mathrm{~g}$ wet wt specimen ${ }^{-1} \mathrm{~d}^{-1}$, respectively. Interestingly, Berghahn (1990) also noted that shrimps were unable to consume the flesh of the fish until it had begun to degrade (after $24 \mathrm{~h}$ ). In a similar study, Evans et al. (1993) examined the response and consumption of whelks to 3 different discard taxa in laboratory choice experiments. Whelks ate swimming crabs Liocarcinus depurator, purple heart urchins Spatangus purpureus and a gadoid fish, the pouting Trisopterus minutus, but not plaice Pleuronectes platessa. Whelks moved most rapidly towards swimming crabs, suggesting that these were the most preferred prey type. Although the rate of energy intake was highest when whelks fed on sea urchins, when fed to satiation they acquired most energy from swimming crabs. When presented with whole animals, whelks fed preferentially on specific body tissues, e.g. they consumed the eyes of pouting first, and never ate the gills or carapace of swimming crabs. Absorption efficiency was highest when fed a diet of swimming crabs (93\%) and lowest when fed pouting $(83 \%)$. These experiments revealed that whelks preferentially consumed the most energetically rich species. These laboratory observations were later validated with trapping experiments using different types of carrion (Ramsay et al. 1997).

These laboratory observations reveal some useful insights into a number of aspects of the use of carrion by scavengers in the field. Firstly, it is clear that many species of scavengers are capable of feeding upon the same types of carrion (e.g. fish), but that some scavengers such as whelks show distinct preferences for particular types of carrion (e.g. swimming crabs) that yield the most energy. Other carrion types are avoided, presumably because they are unable to physically utilise them or for other reasons such as aversion to the tissues of particular species (e.g. plaice). These combined observations suggest that competition and resource partitioning are likely to occur with respect to dead discards that fall to the seabed and moribund animals generated by the direct physical disturbance created by the trawl.

\section{In situ observations}

The limitation of laboratory studies of putative scavenging species is that the observations may not relate to what happens in the field. A number of studies have approached this through direct observation of scavengers attracted to underwater time-lapse still or video cameras baited with moribund discards, through direct time-series observations using divers, or through experimental manipulations in the field and remote sampling. Each of these approaches has offered complimentary information regarding the behaviour of scavengers in the field. Kaiser \& Spencer (1996) recorded the numbers of scavengers feeding on a bag containing bait at a site in the Irish Sea, and found that the main scavengers were dabs Limanda limanda L., whiting Merlangius merlangus L., hermit crabs Pagurus bernhardus L., whelks Buccinum undatum and starfish Asterias rubens. Similar studies have been carried out in Australia in Moreton Bay, Queensland, and the Torres Strait between Australia and Papua New Guinea (Hill \& Wassenberg 1990, Wassenberg \& Hill 1990). In the Moreton Bay prawn fishery, those discards that reached the sea bed were eaten by sand crabs Portunus pelagicus L. and fish (Wassenberg \& Hill 1990). Most of the material from the Torres Strait prawn fishery that reached the sea bed was eaten by teleost fish and sharks (Hill \& Wassenburg 1990). These time-lapse camera observations yield useful insights into arrival times and residence time at food falls. Kaiser \& Spencer (1996) found that the arrival times at fisheries carrion varied according to scavenger mobility. The most mobile scavengers such as dabs, whiting and hermit crabs arrived between 30 and 50 min after deployment of the carrion, while slowermoving scavengers built up in numbers more slowly, with whelks arriving after $7 \mathrm{~h}$. Similarly, peak numbers of different species occurred at different times after the initial food fall, with maximum hermit crab densities at 3 to $14 \mathrm{~h}$, whelks at $12 \mathrm{~h}$ and starfish at $17 \mathrm{~h}$ or longer. In another related study, Ramsay et al. (1997) undertook similar observations at 2 sites within the Irish Sea, one at a site with a muddy sand substratum and the other at a site with a muddy substratum. Observations with baited time-lapse cameras at the muddy sand site showed that the hermit crab $P$. bernhardus was attracted to carrion in greatest abundance and aggregated at densities of up to $330 \mathrm{~m}^{-2}$, and there was a much greater diversity of scavengers at this site. In contrast, there was relatively little scavenging activity at the muddy substratum site, where the edible crab Cancer pagurus appeared to consume the greatest proportion of the carrion. Numbers of each scavenger species at the bait were only partially related to the background population density of each species at each 
site; hence, the differences in attraction to the carrion are probably related to the seabed water current speed at these sites (high at the muddy sand site, low at the muddy site). As a consequence of the different numbers of scavengers attracted to the carrion, the rate of consumption of carrion varied between sites and could be related to the abundance of different scavenger species at the bait.

The numbers of scavengers attracted to fisheries carrion varies among different habitats. In those habitats where scavenger numbers are high and high densities of scavenger aggregate around carrion, there is ample evidence of competition within and among species (Ramsay et al. 1997, Kaiser et al. 1998). Evidence for the latter was particularly apparent for hermit crabs Pagurus bernhardus and Pagurus prideauxi in the Irish Sea. Both of these species are attracted to and consume carrion in laboratory studies. However, direct field observations demonstrate that $P$. prideauxi avoid carrion when large aggregations of $P$. bernhardus occur and that the latter also exclude, through competitive interactions, the smallest individuals in the population.

The consumption time for carrion on the seabed has been ascertained in a number of in situ studies, and varies from 3 to $72 \mathrm{~h}$ (Berghahn 1990, Ramsay et al. 1997, Fonds \& Groenwold 2000, Groenwold \& Fonds 2000). While these consumption times reflect the number of scavengers attracted to the carrion, they are also similar to the time-scale at which scavenger aggregations persist on trawled areas. The latter have been ascertained through comparative studies of experimentally trawled areas with suitable adjacent control areas sampled at times before and after trawl disturbance occurred. All such studies indicate that the abundance of a variety of scavengers increases within trawl-disturbed areas relative to control areas up to $72 \mathrm{~h}$ after the trawl disturbance occurred and thereafter declines (Kaiser \& Spencer 1996, Ramsay et al. 1996, Kaiser et al. 1998, Demestre et al. 2000). This time-scale approximates well the arrival behaviour and patterns of scavengers at baited cameras. Scavenging fauna sampled from within trawl-disturbed areas typically have fuller guts than those sampled from adjacent untrawled areas (Kaiser \& Spencer 1994, Ramsay et al. 1996), and even contain species of carrion that would not be available to them under normal conditions (Kaiser \& Spencer 1994, Link \& Almeida 2002).

\section{How much carrion is produced and where does it go?}

In the North Sea it has been suggested that the total weight of fish discarded annually is in the same order of magnitude as the total landings of the demersal fish- eries (Camphuysen et al. 1993). The total annual quantity of discards and offal in the North Sea has been estimated at 70000 tonnes of offal, 120000 tonnes of roundfish, 200000 tonnes of flatfish and 180000 tonnes of benthic invertebrates (Camphuysen et al. 1993). The mortality of discards varies between different species; some fish such as dragonets Callionymus lyra L. are extremely vulnerable, nearly $100 \%$ die after capture, whilst others, such as the starfish Asterias rubens L., are less susceptible to physical damage and $<1 \%$ die (Kaiser \& Spencer 1995). Nevertheless, there is significant bias introduced into studies that examine posttrawl survival in the absence of natural predators, which can lead to greatly under-estimated mortality rates (Ramsay \& Kaiser 1998). A large proportion of the discarded non-commercial or undersized fish is eaten by seabirds (Furness et al. 1988, Camphuysen et al. 1993), the number taken varying according to the species discarded, as most seabirds eat roundfish in preference to flatfish (Furness 1996, 2003, Furness et al. 2007). It has been suggested that increases in the population sizes of some scavenging seabirds can be linked (in part) to increased food availability in the form of fisheries discards (Furness et al. 1988). Those discards not eaten by seabirds will sink through the water column where some may be eaten by cetaceans and fishes (Hill \& Wassenburg 1990); the remainder sink to the sea bed where they become available as food for benthic scavengers. In the North Sea, it is considered that approximately half of the discarded material from trawlers sinks to the seabed, but this varies from one region to another (Garthe et al. 1996, Furness et al. 2007).

Although the amount of organic material redirected to the seabed may seem large (>300 $000 \mathrm{t}$ ), there is a further source of carrion generated in the path of the trawl through direct physical disturbance. The latter can generate considerable amounts of carrion that varies with gear type and the habitat in which it is employed (Kaiser et al. 2006). Incorporating this additional source of mortality is important if we are to understand the ecological implications of fisheriesgenerated carrion for the scavenging biota of benthic communities (Fonds \& Groenwold 2000).

\section{Trends in the abundance of benthic scavengers}

A number of studies have used long-term datasets to gain an insight into potential changes in scavenger populations. However, Philippart (1998) found no increase in the reported numbers or frequency of landings of scavenger species by Dutch fishermen; indeed, some species such as common whelk Buccinum undatum had become locally extinct. In contrast, Rumohr \& 
Kujawski (2000) compared qualitative historical benthos data (1902 to 1912) with recent data (1986) and found long-term trends in epifauna species composition in the southern North Sea that they attributed to fishery-induced changes. Scavenger and predator species (crustaceans, gastropods and sea stars) were observed more frequently in 1986. There was a marked increase in records of starfish, and the frequency of occurrence of the common whelk had more than doubled. The swimming crab Liocarcinus holsatus also increased markedly Rumohr \& Kujawski (2000). Greenstreet \& Hall (1996) also reported that the abundance of scavenging flatfish such as dabs had also increased during the last century. Although such studies are useful in detecting long-term trends in scavengers, these changes are likely also linked to fisheries-induced reductions in competing species and top predators such as cod, as well as long-term changes in the environment.

\section{MATERIALS AND METHODS}

Demersal fisheries kill benthic invertebrates as the fishing gear is dragged across the seabed and generate carrion through discarding of bycatches. These killed animals and carrion contribute to secondary production of animals that feed on this material and therefore can cause a short-term increase in local production. Nevertheless, previous studies have shown that chronic bottom trawling reduces the overall biomass and production of benthic invertebrate communities due to the removal of the large biomass of large and long-lived fauna (Hiddink et al. 2006b). Here, we partition out the energy subsidy generated through fisheries activities to estimate its importance for marine carnivores.

Modelling benthic production and carrion production. We used an existing size-based model to calculate the amount of benthic production and production of benthic carrion that occurs in the North Sea under a quantified regime of different intensities of trawling disturbance. Details of the development and use of the model are given in Duplisea et al. (2002) and Hiddink et al. (2006b). In brief, the model contained 32 state variables, in 2 faunal groups (soft- and hard-bodied macrofauna). Growth of the population biomass in each body mass-organism type compartment was modelled by modifying Lotka-Volterra competition equations to give the population biomass flux for a compartment. The size-based approach of the model is advantageous because it can be applied to a wide range of environments for which the physical forcing parameters are known. The interaction between habitat type and trawling effects was modelled by in- cluding relationships between growth, mortality and the environment in the model. Thus, sediment type affected trawling mortality, sediment erosion rates affected natural mortality, the effect of bed shear stress modified population growth rate and the chlorophyll $a$ content of the sediment affected carrying capacity. The interaction of organisms with the environment is independent of body type and depends solely on their lifehistory parameters. As soft- and hard-bodied invertebrates have different life-history parameters in the model, at the same body size, soft-bodied animals have a faster life history than hard-bodied animals; therefore, hard-bodied animals dominate stable habitats and soft-bodied animals prevail in the more dynamic and disturbed habitats. The model was validated by correlating observed and predicted values of biomass at each of 33 stations that were subject to a known range of trawling intensities in 4 shallow, softsediment areas in the North Sea. The sources of environmental data used to parameterise the model and the sensitivities of the model to changes in parameters were described by Hiddink et al. (2006b). We recalculated the model predictions from ash free dry weight (AFDW) to wet weight (Wet wt) using a conversion factor of 6.73 (Brey 2001).

In the original model, production was the sum of carrion and 'normal' production. Carrion production in the model was calculated separately for animals larger and smaller than $0.5 \mathrm{~g}$ as the biomass of animals that were killed by trawling in a year. The 'normal' production is defined as the biomass of all animals that die in a year excluding carrion production. The model was used to examine the effect of bottom trawling on benthic production in the Dutch and UK sectors of the North Sea $\left(125000 \mathrm{~km}^{2}\right)$, in the area south of $56^{\circ} \mathrm{N}$ for $9 \mathrm{~km}^{2}$ cells. Production and biomass in the presence and absence of trawling were determined by running the model for 1500 time steps of $30 \mathrm{~d}$. The general effect of trawling on production is illustrated for 2 habitats with different sensitivities to bottom trawling. Sensitivity $S$ was defined based on the time it takes for production to recover to $90 \%$ of its pristine values (as calculated with the size-based model described by Hiddink et al. 2006a, 2007):

$$
S_{\mathrm{p}}=1-\mathrm{e}^{-0.25 T_{\mathrm{p}}}
$$

where $T_{\mathrm{P}}$ is the time that it takes the productivity of the benthic community to recover from the trawling impact.

Trawling frequency was calculated from European Community Satellite Vessel Monitoring System (VMS) data (for more details see Dinmore et al. 2003, Hiddink et al. 2006b). For the Dutch beam-trawling fleet, VMS records were not available for all vessels. Therefore, effort distribution, as recorded by the VMS system, 
was corrected to represent total trawling effort as recorded in logbooks by fishers (G. J. Piet, RIVO, unpubl. data). To express trawling frequency, the North Sea was gridded at a scale of $9 \mathrm{~km}^{2}$ and trawling intensity was expressed as the number of times each $9 \mathrm{~km}^{2}$ grid cell was swept each year. In this calculation it was assumed that trawlers fished at a speed of 5 knots, with a total fishing gear width of $24 \mathrm{~m}$ (2 beam trawls each of $12 \mathrm{~m}$ width or 1 otter trawl of $24 \mathrm{~m}$ width). Therefore, at a VMS record frequency of once per $2 \mathrm{~h}, 1$ satellite monitoring record in 1 grid cell represents a trawled area of $0.449 \mathrm{~km}^{2}$ and 1 record in 1 grid cell in a $1 \mathrm{yr}$ period represents a trawling intensity of $0.050 \mathrm{yr}^{-1}$.

Calculation of carrion from discards. In addition to the carrion generated directly through bottom trawl disturbance, we calculated the amount of carrion generated through discarding, using the values reported by Garthe et al. (1996). In their study, Garthe et al. (1996) calculated the different amounts of fisheries discards generated by trawl fisheries in different spatial areas of the North Sea and estimated the amount of this material consumed by scavenging seabirds from direct observations of the feeding behaviour of seabirds while at sea. Our model extended to $125000 \mathrm{~km}^{2}$ of the North Sea and covered $40 \%$ of the central west, $49 \%$ of the central and $60 \%$ of the southern areas of the North Sea, as defined by Garthe et al. (1996), and discard estimates were scaled to the modelled area. For each of these areas, we calculated the proportion of discards that were not consumed by seabirds and used these to correct for the actual weights of discarded material. In the original calculations by Garthe et al. (1996), they reported separately the benthic invertebrate component of discards; however, this component is already accounted for in our estimate of instantaneous mortality in the benthos as a result of trawling (i.e. the difference in the benthos observed before and after a trawling event includes the benthos killed on the seafloor and that retained within the trawl net and subsequently discarded).

\section{RESULTS}

The mean instantaneous mortality varied among taxa, with different gear types (otter trawls vs. beam trawls) and among habitats (Table 1). Knowing the difference in the instantaneous mortality of benthos with gear type and habitat enabled us to integrate these differences through modelling. Accordingly, we calculated the change in benthic production for different body-sized animals in response to different intensities of trawling in the North Sea. We showed only the output for the most sensitive seabed habitat ( $S=0.8$ to 1.0 ) and the second least sensitive seabed habitat $(S=0.2$ to
0.4) for illustrative purposes. The latter covered $42.6 \%$ of the area of the North Sea considered in the present study (Tables $2 \& 3$, Fig. 1). The output for both habitat types indicates that the production of benthic carrion is trivial compared with total benthic production, even when overall benthic production is reduced by the direct effects of trawling disturbance. As reported previously, the smaller body-sized components of the fauna $(<0.5 \mathrm{~g})$ increase their production under a regime of irregular fishing disturbance (disturbed once every 0.25 to 4 times $\mathrm{yr}^{-1}$ (Fig. 2). It is clear from the satellite monitoring data that most areas of the seabed are trawled relatively infrequently, while others are trawled intensively. Interestingly, the response of the production of carrion is quadratic, as reported elsewhere (Ramsay et al. 2000), such that the production of carrion increases under intermediate regimes of disturbance and then declines again as fishing frequency increases above 2 to 4 times $\mathrm{yr}^{-1}$ depending on the habitat sensitivity.

Using the corrected values (see Table 2 legend) given in Garthe et al. (1996), we calculated that excluding benthic discards, the total amount of material recycled to the seabed (roundfish, flatfish, elasmobranchs and offal) for the central west, central and

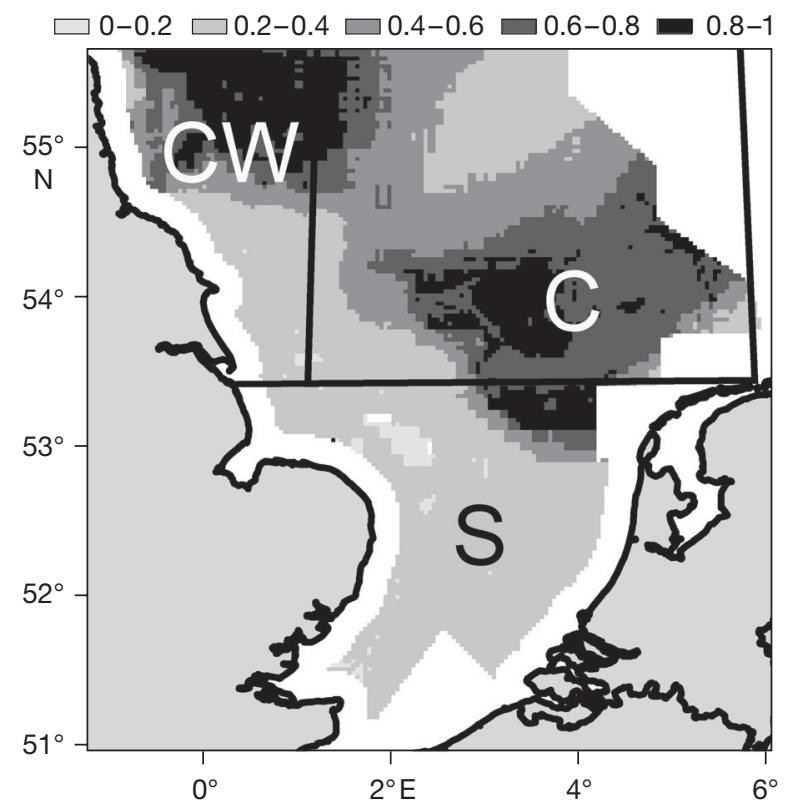

Fig. 1. Habitat sensitivity (see key) in the southern North Sea calculated from Eq. (1) (see 'Materials and methods' section) (from Hiddink et al. 2007). Also shown are the boundaries of the marine areas for which Garthe et al. (1996) calculated the amount of discards produced by fisheries in different regions of the North Sea (CW: central west; C: central; S: south), but note that the size of the areas used by Garthe et al. (1996) extends beyond the boundaries of the areas for which we were able to model benthic production, thus we applied a correction factor to their published estimates 
Table 2. Calculated discards (excluding benthic invertebrates) (t wet wt $\mathrm{yr}^{-1}$ ) for the central west (CW), central (C), and southern (S) areas of the North Sea using the figures in Garthe et al. (1996). The estimates for each area were then corrected, as the benthic production model extended to only $125000 \mathrm{~km}^{2}$ of this estimates for benthic invertebrates are excluded from the calculation, as they are integrated in our estimate of mortality of the benthos (see Table 3)


area which covered a total of $265466 \mathrm{~km}^{2}$. The correction factors applied to each area were: CW: 0.403, C: 0.493, S: 0.605 . Note that the Garthe et al. (1996)

$372956 \mathrm{t} \mathrm{yr}^{-1}$ compared with a total benthic production under the current regime of fishing disturbance of $5185369 \mathrm{t} \mathrm{yr}^{-1}$, excluding the contribution of carrion. This also ignores the contribution of those organisms that pass through the meshes of the net, but that subsequently die. The loss of production from trawling due to biomass removal (excluding the contribution of carrion) equates to $1702165 \mathrm{t} \mathrm{yr}^{-1}$. This means that carrion generated by direct physical disturbance to the seabed is equivalent to only $15 \%$ of the benthic production that is lost due to trawling. Adding the contribution of carrion from discards increases the biomass of carrion to $22 \%$ of the loss of production in the benthos due to trawling. Garthe et al. (1996) estimated that the amount of benthic material discarded to the seabed in the area considered in the present study was $54970 \mathrm{t} \mathrm{yr}^{-1}$. The latter represents only $21 \%$ of our modelled estimate of carrion production (255 $783 \mathrm{t} \mathrm{yr}^{-1}$ ) that takes into account mortality on the seabed (Table 3 ).

\section{DISCUSSION}

southern regions of the North Sea amounted to carrion produced by the direct physical disturbance created by trawling at the seabed was $255783 \mathrm{t} \mathrm{yr}^{-1}$ (Table 3). This sums to give a total production of carrion made available to benthic scavengers of

Table 3. Benthic production modeled for a $125000 \mathrm{~km}^{2}$ area of the North Sea (see Fig. 1) showing the component of benthic production generated through carrion resulting from trawling (showing Garthe et al.'s [1996] estimate corrected for the same area for comparison) and the production of the remaining living benthic community

\begin{tabular}{|lc|}
\hline & $\begin{array}{c}\text { Benthic carrion } \\
\text { production }\left(\mathrm{t}^{-1}\right)\end{array}$ \\
\hline $\begin{array}{l}\text { Benthic production associated with } \\
\text { carrion generated by trawling }\end{array}$ \\
Animals $<5 \mathrm{~g}$ & 161252 \\
Animals $>5 \mathrm{~g}$ & 94531 \\
Total & 255783 \\
Corrected estimated benthic discards & 54970 \\
(Garthe et al. 1996) & \\
Benthic production generated from the & \\
remaining living component of the benthos & \\
Animals $<5 \mathrm{~g}$ & 4032530 \\
Animals $>5 \mathrm{~g}$ & 1152838 \\
Total & 5441152 \\
\hline
\end{tabular}

Increases in the populations of avian scavengers in the North Sea and elsewhere have been linked, in part, to the activities associated with discarding practices from fisheries. However, to date, no similar increases in benthic scavengers have been recorded for either invertebrates or fishes (Ramsay et al. 2000). Nevertheless, scavenger species may become the dominant macrofauna in areas subjected to intensive bottom fishing activities without changing their abundance (i.e. other species are simply removed, while scavenger populations do not change). Fonds \& Groenwold (2000) used an energetic approach to calculate the energy requirements of benthic carnivores relative to the amount of carrion generated through fishing activities for 4 study areas in the North Sea. They calculated that the fisheries in this region generated $1.27 \mathrm{~g}$ AFDW $\mathrm{m}^{-2} \mathrm{yr}^{-1}$, which was approximately enough to sustain benthic carnivores for $10 \mathrm{~d}$ given maximum consumption rates at $16^{\circ} \mathrm{C}$. Converting the combined estimates of wet weight of carrion produced to AFDW using a conversion factor of 6.73, Brey (2001) gives a value of $0.556 \mathrm{~g}$ AFDW m-2 $\mathrm{yr}^{-1}$ for the area of the North Sea considered in the present study. These 2 independent estimates are similar in terms of magni- 


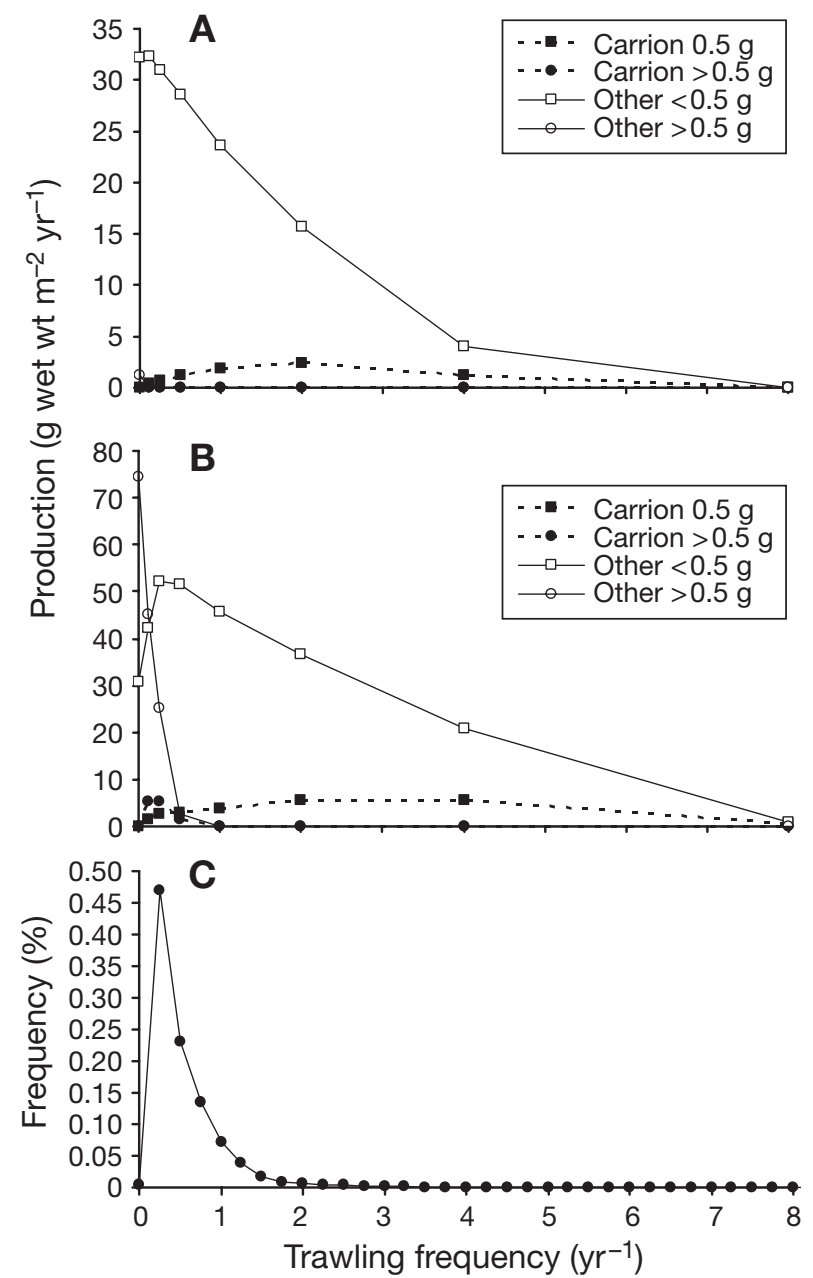

Fig. 2. $(\mathrm{A}, \mathrm{B})$ Modelled production of benthic invertebrates at different trawling frequencies, separate for large and small animals (0.5 g wet weight [WW]) and for normal production (excluding carrion) and carrion production by trawling impacts. (A) Low sensitivity habitat, low primary production, high tidal shear stress, high wave erosion, sandy or gravely sediment. $S=0.2$ to 0.4 (Hiddink et al. 2007). (B) High sensitivity habitat, higher primary production, low tidal shear, low wave erosion, sand sediment. $S=0.8$ to 1 (Hiddink et al. 2007). (C) Trawling frequencies in the southern North Sea (area covered and methodology, see Hiddink et al. 2007)

tude, and we would reiterate the conclusions of Fonds \& Groenwold (2000) that there is likely insufficient carrion generated by fishing activities to stimulate an increase in the populations of these taxa at a North Sea-wide scale. A supply of carrion that can sustain scavengers for $10 \mathrm{~d}$ represents an increase in yearly food supply of $2.7 \%$, suggesting that this would lead to a proportionate increase in the abundance of scavengers. Most scavengers in the North Sea are facultative and rely on food resources other than carrion. However, chronic bottom trawling not only produces carrion, but it also substantially reduces the production of the remaining benthic community, which forms the natural food source consumed by facultative scavengers. In the North Sea, benthic invertebrate production is reduced by $21 \%$ compared to a situation without bottom trawling (Hiddink et al. 2006b), and this means that fisheries are likely to reduce rather than increase food availability for scavengers.

Given the variation in fishing disturbance frequency across the North Sea it is possible to consider that in some areas conditions may exist that would promote scavenger populations. A cursory examination of Fig. 2 might indicate that, at the lower levels of fishing frequency, carrion does offset losses of production due to fishing; however, occurrences are so infrequent (every 4 to $8 \mathrm{yr}$ ) that they clearly do not meet the criteria defined by Polis et al. (1996): if energy subsidies are to have population level effects, they must be large enough and occur frequently and in a predictable manner. These criteria are met for avian scavengers, as they are able to search widely for (and find) trawlers on a daily basis and thereby remove the unpredictability of the supply of discards.

Despite our conclusions, carrion generated from pelagic fisheries may have a positive population effect on scavengers. Pelagic fisheries do not interact with the seabed; hence, there is no net loss of benthic biomass or production due to interactions with the gear. Assuming that most roundfish discards originate from pelagic fisheries and that the other sources of discards originate from demersal fisheries (Table 2), pelagic fisheries contribute $\sim 11 \%$ of total discard flux to the seabed. This implies that discards of pelagic fisheries in areas where there is no bottom trawling could have a significant effect on benthic scavenger populations. We hypothesize that scavengers may be more abundant in areas that are exploited exclusively by pelagic fisheries compared to areas where bottom-trawl fisheries occur. This prediction could be tested by combining detailed fishing effort distribution data with sampling of benthic invertebrate communities. Given the variation in pelagic fishing frequency across the North Sea, it is possible to consider that the latter conditions occur in some areas (Greenstreet et al. 1999).

Secondary effects of fishing may also have an impact upon benthic scavenger populations that create bottlenecks to population growth. Many of the benthic scavengers considered in previous studies are themselves subject to fisheries mortality, which is often underestimated in controlled laboratory survival experiments (e.g. Berghahn 1990, Kaiser \& Spencer 1995). Examination of post-fishing mortality in natural conditions revealed that whelks were extremely susceptible to predation by hermit crabs and starfish compared with whelks that were unaffected by contact with a fishing gear (Ramsay \& Kaiser 1998). Fishing may also affect the availability of essential resources such as gastro- 
pod shells for hermit crabs. In a comparative study of the North and Irish Seas, Kaiser et al. (2002) found evidence that hermit crabs in the North Sea were smaller in body size in accordance with a lower availability of suitable gastropod shells due to the decline in whelk populations. Finally, most benthic scavengers on continental shelves are facultative scavengers whose morphology and physiology are not adapted to feeding on sporadic food falls and gorge feeding. However, amphipod scavengers fulfil these criteria, and are highly abundant at food falls in the North and Irish Seas (Ramsay et al. 1997, Groenwold \& Fonds 2000). This group remains relatively little studied in terms of their population dynamics, but they would currently seem the most likely candidates to benefit from the carrion generated by fisheries as their life histories are adapted to infrequent pulses of food to the seabed. In an evolutionary context, amphipod scavengers would seem the only invertebrates that have evolved to cope with sporadic food falls. It is unlikely that such evolutionary adaptations could occur in other groups over the time-scale of the increase in commercial fisheries (last $40 \mathrm{yr}$ ). From an energetic perspective, it seems feasible that some fish could exist exclusively as scavengers (Ruxton \& Huston 2004), but no evidence appears that would support this for large macroinvertebrates (Fonds \& Groenwold 2000).

Although our modelling approach produces estimates of the amount of carrion generated through trawling, the figures derived are similar to those of other researchers whose calculations were based on empirical observations (e.g. Berghahn 1990, Fonds \& Groenwold 2000). While food falls of carrion would not appear to offset the loss in total production attributed to the direct effects of fishing, the response of scavengers in the deep-sea environment may be quite different. With the expansion of commercial fisheries into ever deeper environments, the role of fisheries-generated carrion in deep-sea food webs warrants further investigation. Fisheries-generated carrion in the deep sea may well lead to population changes in a large range of scavenging species that are specifically adapted to exploit sporadic food falls, and Ruxton \& Houston (2004) have demonstrated already the energetic feasibility of an obligate scavenging lifestyle for large-bodied fishes.

Acknowledgements. This research was funded in part by DEFRA MF0731. The authors thank 2 anonymous referees for comments that improved the manuscript.

\section{LITERATURE CITED}

Alverson DL, Freeberg MH, Pope JG, Murawski SA (1994) A global assessment of fisheries bycatch and discards. FAO Fisheries Technical Paper 339, FAO, Rome
Berghahn R (1990) On the potential impact of shrimping on trophic relationships in the Wadden Sea. In: Barnes M, Gibson RN (eds) Trophic relationships in the marine system. Aberdeen University Press, Aberdeen, p 130-140

Bergman MJN, van Santbrink JW (2000) Mortality in megafaunal benthic populations caused by trawl fisheries on the Dutch continental shelf in the North Sea in 1994. ICES J Mar Sci 57:1321-1331

Brey T (2001) Population dynamics in benthic invertebrates. A virtual handbook. Version 01.2. Alfred Wegener Institute for Polar and Marine Research, Bremerhaven. Available at www.awi-bremerhaven.de/Benthic/Ecosystem/ FoodWeb/Handbook/main.html

Britton JC, Morton B (1994) Marine carrion and scavengers. Oceanogr Mar Biol Annu Rev 32:369-434

Broadhurst MA, Suuronen P, Hulme A (2006) Estimating collateral mortality from towed fishing gear. Fish Fish $7: 180-218$

Camphuysen CJ, Ensor K, Furness RW, Garthe S, Huppop O, Leaper G, Offringa H, Tasker ML (1993) Seabirds feeding on discards in winter in the North Sea. Netherlands Institute for Sea Research, Den Burg, Texel

Demestre M, Sánchez P, Kaiser MJ (2000) The behavioural response of benthic scavengers to otter trawling disturbance in the Mediterranean. In: Kaiser MJ, de Groot SJ (eds) The effects of trawling on non-target species and habitats: biological, conservation and socio-economic issues. Blackwell Science, Oxford, p 121-129

Dinmore TA, Duplisea DE, Rackham BD, Maxwell DL, Jennings S (2003) Impact of a large-scale area closure on patterns of fishing disturbance and the consequences for benthic communities. ICES J Mar Sci 60:371-380

Duplisea DE, Jennings S, Warr KJ, Dinmore TA (2002) A sizebased model of the impacts of bottom trawling on benthic community structure. Can J Fish Aquat Sci 59:1785-1795

Evans PL, Kaiser MJ, Hughes RN (1993) Behaviour and energetics of whelks, Buccinum undatum (L.), feeding on animals killed by beam trawls. J Exp Mar Biol Ecol 197:51-62

Fonds M, Groenwold S (2000) Food subsidies generated by the beam trawl fishery in the southern North Sea. In: Kaiser MJ, de Groot SJ (eds) The effects of trawling on non-target species and habitats: biological, conservation and socio-economic issues. Blackwell Science, Oxford, p 130-150

Furness RW (1996) A review of seabird responses to natural or fisheries-induced changes in food supply. In: Greenstreet SPR, Tasker ML (eds) Aquatic predators and their prey. Blackwell Scientific Publications, Oxford, p 168-173

Furness RW (2003) Impacts of fisheries on seabird communities. Sci Mar 67(Suppl 2):33-45

Furness RW, Hudson AV, Ensor K (1988) Interactions between scavenging seabirds and commercial fisheries around the British Isles. In: Burger J (ed) Seabirds and other marine vertebrates: competition, predation and other interactions. Columbia University Press, New York, p 240-268

Furness RW, Edwards AE, Oro D (2007) Influences of management practices and of scavenging seabirds on availability of fisheries discards to benthic scavengers. Mar Ecol Prog Ser 350:235-244

Garthe S, Camphuysen CJ, Furness RW (1996) Amounts of discards by commercial fisheries and their significance as food for seabirds in the North Sea. Mar Ecol Prog Ser 136:1-11

Greenstreet SPR, Hall SJ (1996) Fishing and groundfish assemblage structure in the northwestern North Sea: an analysis of long-term and spatial trends. J Anim Ecol 65:577-598 
Greenstreet SPR, Spence FE, McMillan JA (1999) Fishing effects in northeast Altantic shelf seas: patterns in fishing effort, diversity and community structure. V. Changes in structure of the North Sea groundfish species assemblage between 1925 and 1996. Fish Res 40:153-183

Groenwold S, Fonds M (2000) Effects on benthic scavengers of discard and damaged benthos produced by the beamtrawl fishery in the southern North Sea. ICES J Mar Sci 57:1395-1406

Hall SJ (1994) Physical disturbance and marine benthic communities: life in unconsolidated sediments. Oceanogr Mar Biol Annu Rev 32:179-239

Hall SJ, Mainprize BM (2005) Managing by-catch and discards: How much progress are we making and how can we do better? Fish Fish 6:134-155

Hiddink JG, Jennings S, Kaiser MJ (2006a) Recovery status as an indicator of the large scale ecological impact of bottom trawling. Ecosystems 9:1190-1199

Hiddink JG, Jennings S, Kaiser MJ, Queirós AM, Duplisea DE, Piet GJ (2006b) Cumulative impacts of seabed trawl disturbance on benthic biomass, production and species richness in different habitats. Can J Fish Aquat Sci 63: 721-736

Hiddink JG, Jennings S, Kaiser MJ (2007) Assessing and predicting the relative ecological impacts of disturbance on habitats with different sensitivities. J Appl Ecol 44:405-413

Hill B, Wassenberg T (1990) Fate of discards from prawn trawlers in Torres Strait. Aust J Mar Freshw Res 41:53-64

Kaiser MJ, Moore PG (1999) Obligate marine scavengers: Do they exist? J Nat Hist 33:475-481

Kaiser MJ, Spencer BE (1994) Fish scavenging behaviour in recently trawled areas. Mar Ecol Prog Ser 112:41-49

Kaiser MJ, Spencer BE (1995) Survival of by-catch from a beam trawl. Mar Ecol Prog Ser 126:31-38

Kaiser MJ, Spencer BE (1996) The behavioural response of scavengers to beam-trawl disturbance. In: Greenstreet S, Tasker M (eds) Aquatic predators and their prey. Blackwell Scientific Publications, Oxford

Kaiser MJ, Ramsay K, Hughes RN (1998) Can fisheries influence the outcome of interspecific competition in sympatric populations of hermit crabs? J Nat Hist 32:521-531

Kaiser MJ, Collie JS, Hall SJ, Jennings S, Poiner IR (2002) Modification of marine habitats by trawling activities: prognosis and solutions. Fish Fish 3:114-136

Kaiser MJ, Collie JS, Hall SJ, Jennings S, Poiner IR (2002) Modification of marine habitats by trawling activities: prognosis and solutions. Fish Fish 3:114-136

Kaiser MJ, Clarke KR, Hinz H, Austen MCV, Somerfield PJ, Karakassis I (2006) Global analysis of response and recovery of benthic biota to fishing. Mar Ecol Prog Ser 311: $1-14$

Editorial responsibility: Howard Browman (Associate Editorin-Chief), Storebø, Norway
Link JS, Almeida FP (2002) Opportunistic feeding of longhorn sculpin (Myoxocephalus octodecemspinosus): Are scallop fishery discards an important food subsidy for scavengers on Georges Bank? Fish Bull 100:381-385

Paetzold A, Schubert C, Tockner K (2005) Aquatic terrestrial linkages along a braided river: riparian arthropods feeding on aquatic insects. Ecosystems 8:748-759

Philippart CJM (1998) Long-term impact of bottom fisheries on several by-catch species of demersal fish and benthic invertebrates in the south-eastern North Sea. ICES J Mar Sci 55:342-352

Polis GA, Holt RD, Menge BA, Winemiller KO (1996) Time, space and life history: influences on food webs. In: Polis GA, Winemiller KO (eds) Food webs: integration of pattern and dynamics. Chapman \& Hall, New York, p $438-447$

Polis GA, Anderson WB, Holt RD (1997) Toward an integration of landscape and food web ecology: the dynamics of spatially subsidized food webs. Annu Rev Ecol Syst 28:289-316

Ramsay K, Kaiser MJ (1998) Demersal fishing increases predation risk for whelks Buccinum undatum (L.). J Sea Res 39:299-304

Ramsay K, Kaiser MJ, Hughes RN (1996) Changes in hermit crab feeding patterns in response to trawling disturbance. Mar Ecol Prog Ser 144:63-72

Ramsay K, Kaiser MJ, Moore PG, Hughes RN (1997) Consumption of fisheries discards by benthic scavengers: utilisation of energy subsidies in different marine habitats. J Anim Ecol 86:884-896

Ramsay K, Kaiser MJ, Rijnsdorp AD, Craeymeersch J, Ellis J (2000) The impact of beam trawling on populations of the benthic scavenger Asterias rubens L. In: Kaiser MJ, de Groot SJ (eds) The effects of trawling on non-target species and habitats: biological, conservation and socioeconomic issues. Blackwell Science, Oxford, p 151-162

Rumohr H, Kujawski T (2000) The impact of trawl fishery on the epifauna of the southern North Sea. ICES J Mar Sci 57:1389-1394

Ruxton GD, Houston DC (2004) Energetic feasibility of an obligate marine scavenger. Mar Ecol Prog Ser 266:59-63

Smith CR (1985) Food for the deep sea: utilization, dispersal, and the flux of nekton falls at the Santa Catalina Basin floor. Deep-Sea Res 32:417-442

Stockton WL, DeLaca TE (1982) Food falls in the deep sea: occurrence, quality and significance. Deep-Sea Res 29:157-169

Wassenberg T, Hill B (1990) Partitioning of material discarded by prawn trawlers in Moreton Bay. Aust J Mar Freshw Res $41: 27-36$

Submitted: January 23, 2007; Accepted: July 27, 2007

Proofs received from author(s): November 12, 2007 